\title{
Fiqh Solutions Against Usury (Riba) Practices In Conventional Banking
}

\author{
Asgaft Asy-syad Rasyid ${ }^{1}$
}

ISEBI Lecturer \& Doctoral Candidate IIQ Jakarta Email: asgaftasysyadrasyid@ gmail.com

\begin{abstract}
The discussion of usury as if there had never been an endpoint, from the time of the companions of the prophet to contemporary Islamic scholars. Especially when the practice of usury appears in banking financial institutions. The majority of contemporary Islamic scholars such as Yûsuf Al-Qaradhāwi, view that the operation of conventional banks based on interest is unlawful, because this is the same as usury. In line with the fatwa of the Indonesian Ulema Council (MUI), which states that all forms of money interest practices within financial institutions are illegal. Over time, financial transactions (muamalah) carried out by someone also need instruments of financial institutions. So, a solution is needed for a Muslim to conduct financial transactions with the banking world. The fiqh study provides space for Muslims to conduct financial transactions both with individuals and with an institution while remaining based on applicable Islamic law.

Keywords: Usury, Selling-Buying, Conventional Bank, and Islamic Bank
\end{abstract}

\section{INTRODUCTION}

Islamic law regulates all aspects of human life, starting with those related to the relationship to Allah. which is called ibâdah, up to those related to relations between human beings, called muâmalah.

Sholat, zakat, fasting, hajj and other worships are included in the scope of 'ibâdah, while those included in the category muâmalah are such as marriage, buying and selling and those related to it, jinâyat ('uqûbât, hudûd and criminal law), inheritance, judiciary, khilâfah/siyâsah (constitutional law/Islamic politics) and jihad. ${ }^{1}$ Both of these categories (ie 'ibâdah and mu' âmalah) have been arranged by Islam based on the texts of the Qur'an, Hadith, and also the opinions of the Islamic scholars (ulama).

One of the things included in the mu'âmalah category is financial transactions, where there are always parties who have excess money while the other party lacks so that the money is needed. In the state monetary system, the concept is known as the Bank.

Bank is a term that has the meaning of a financial intermediary that functions as an intermediary medium, namely to collect funds from the public in the form of deposits (parties with excess funds) and redistribute the funds to other people who need them in the form of credit. ${ }^{2}$ Bank practices have been

\footnotetext{
${ }^{1}$ A. Munif. Suratmaputra, Hukum Islam Problematika dan Solusinya, (Jakarta: Pustaka Firdaus, 2016), cet. ke-1, h. 9

${ }^{2}$ Kasmir, Bank dan Lembaga Keuangan Lainnya, (Jakarta: PT. RajaGrafindo, 2005), h. 24.
} 
6 | Asgaft Asy-syad Rasyid: Figh Solutions Againts Usury (Riba) Practices in Conventional Banking

carried out since 1587 in Venice Italy and began to enter Indonesia since Dutch colonialism, which generally transacted with the principle of usury (riba) or in conventional banking terms called interest. ${ }^{3}$

In Islamic law, usury is something that is forbidden for a Muslim. Even included in the great sin. Sayyid Qutb (d. 1966) states that usury is the most contested act, there is no threat of Allah that is harder than the threat to usury. Among them God declares war on usury eaters ${ }^{4}$.

In the Qur'an the word "usury" is very much mentioned in different letters and verses. While related to the practice and the law, there are 18 verses that explain the prohibition of usury which is gradually reduced, namely 2 verses in QS. Ar-Rûm, 2 verses in QS. An-Nisâ ', 7 verses in QS. Âli 'Imrân, and 7 verses in QS. Al-Baqarah. ${ }^{5}$

This is interesting because the number of verses is far more than the prohibition verses on other things, such as liquor, adultery, pork, stealing and so on $^{6}$, so that it further strengthens that usury is a very big sin. And if a case is repeated or mentioned many times and more than any other case, of course this has strong reasons in it, especially those things contained in the word of Allah. Not to mention if added to the hadiths that also speak volumes about the prohibition of usury.

But in practice, financial institutions in Indonesia are still controlled by institutions that use the interest system, meaning that the Indonesian people still prefer these institutions rather than Islamic financial institutions. whereas the background of the Indonesian people is the largest Muslim community, reaching $87.2 \% .^{7}$

This paper will discuss a little about how to avoid usury in banking, which is preceded by a brief discussion about buying and selling and usury, then the similarities and differences between Islamic banking and conventional banking, which in the end will be given an understanding that it is better and more profitable Islamic banking.

\footnotetext{
${ }^{3}$ Kasmir, Bank dan Lembaga Keuangan Lainnya, h. 27

${ }^{4}$ Sayyid Quthb, Tafsir Ayat-Ayat Riba (Mengupas Persoalan Riba Sampai ke Akar-akarnya), (Jakarta: Wali Pustaka, 2018), cet. ke-1, h. 8-9

${ }^{5}$ See more on: Sayyid Quthb, Tafsir Ayat-Ayat Riba, h. xiv; M. Ali Ash-Shabuni, Ringkasan Tafsir Ibnu Katsir, (Bandung: Jabal, 2018), cet. ke-4, h. 174; Jalaluddin Al-Mahalli \& As-Suyuti, Terjemahan Tafsir Jalalain, (Bandung: Sinar Baru Algresindo, 2018), Jilid I, h. 153-156; Allamah Kamal Faqih Imani, Tafsir Nurul Qur'an, (Jakarta: Al-Huda, 2003), Jilid III, h. 57-58; M. Quraish Shihab, Tafsir Al Misbah, (Jakarta: Lentra Hati, 2011), Vol. 1, cet. ke-4, h. 711-729; Muhammad Amin Suma, Tafsir Ayat Ekonomi, (Jakarta: Amzah, 2018), cet. ke-3, h. 164-178. others

${ }^{6}$ Prohibiting liquor 4 verses, prohibiting pork 3 verses, adultery 1 verse, stealing 1 verse, and

${ }^{7}$ Census data of BPS in 2018.
} 


\section{LITERATURE REVIEW}

\section{SELLING-BUYING AND USURY}

\section{Definition of Selling-buying}

In terms of selling-buying in fiqh it is called al-bai' which means selling, replacing, and exchanging something with something else. The word al-bai' in Arabic is sometimes used for the understanding of the opponent, namely the word ash-syirâ' (buy). Thus, said al-bai' means "selling", and at the same time also means "buy". While according to the term means to exchange property with assets by mutual mutual support between the two parties who make the exchange. ${ }^{8}$

While the meaning of selling-buying in terms of the mu âmalah mâliyah transaction that is practiced in a Islamic bank is known as murâbahah, which is a selling-buying contract for a particular item, where the seller clearly states the item being traded, including the purchase price of the goods to the buyer. Then it requires a certain amount of profit. The purpose of this murâbahah contract is to facilitate customers to make purchases in order to meet their needs, such as: consumer goods (houses, vehicles), inventory of merchandise, raw materials or production auxiliaries, capital goods, and other assets that are not against sharia and approved by bank. ${ }^{9}$ From the above definition can be concluded as follows:

a. Buying and selling is done by two people (groups) who exchange each other;

b. The activity of exchanging is carried out on an item or something that is punished as an item (money or check), which has benefits for both parties;

c. Something that is not in the form of goods or something punished not like goods, the law is not valid for sale, such as labor or services, it is not called buying and selling but is called ujrah;

d. Performed in a special way that is based on the pleasure of two parties and goods that are used as a means of exchange known by two parties.

\section{Understanding Usury}

In Arabic, usury means az-ziyâdah which means "additional". So, everything that increases, in the form of objects and benefits can be interpreted usury..$^{10}$ It also means developing (numuww), enlarging ((uluww) and increasing (irtifấ'). ${ }^{11}$

Whereas according to the interpreters and jurists' terms, usury means adding the burden to the debtor in return for the suspension of the time of

\footnotetext{
${ }^{8}$ Hasan Ayyûb, Fiqh al-Mu âmalât al-Mâliyah fî̀ al-Islâm, (Cairo: Dâr as-Salâm, 2010), cet. ke- 1 , h. 7

${ }^{9}$ Ahmad Ifham, Ini Lho Bank Syariah (Memahami Bank Syariah dengan Mudah), (Jakarta: Gagas Media, 2015), h. 127-128

${ }^{10}$ Muhammad Amin Suma, Tafsir Ayat Ekonomi, h. 170.

${ }^{11}$ Majma' al-Lughah al-'Arabiyah, Al-Mu 'jam al-Wasîth, (Cairo: Maktabah asy-Syurûq adDawliyah, 2004), cet. ke-4, h. 356
} 
8 | Asgaft Asy-syad Rasyid: Figh Solutions Againts Usury (Riba) Practices in Conventional Banking

payment ${ }^{12}$; or it can be interpreted also by adding a measure when exchanging ribawi commodities (gold, silver, wheat, sya'ir, dates, and salt) of the same type; or exchange of gold with silver and food with food by non-cash means ${ }^{13}$; or in a simple language riba is interpreted as "the addition of basic assets without the existence of real business transactions. ${ }^{14}$

From the description of the definition of usury, scholars and interpreters of the jurisprudence divided usury into two types, namely ${ }^{15}$ :

a. Riba Qardh or Riba Nasî'ah is usury (additional) that occurs in debt-related transactions that do not meet the profit criteria, which arise with the risks and results of the business, and appear with the costs (non-underlying contract); or in other words, there is an addition that has been determined at the beginning of the transaction, which is taken by the lender from the person who received the loan in return for repayment of the debt owed. ${ }^{16}$ Riba qardh can also be called riba jahiliyah, which is a debt paid in excess of the amount lent, because the borrower is unable to return the loan funds at the stipulated time. For example, A borrowed Rp. 1 million to B for 1 month, when at maturity (1 month), A cannot pay it off, then B will give an extension of time with condition A must add more payments than the initial debt, which is Rp. 1 million, and so on. ${ }^{17}$

b. Riba Fadhl or Riba Buŷ̂ (selling-buying usury), namely usury arising from the exchange of similar goods of different quality or quantity or different time of delivery (not cash). Can also be interpreted as exchanging an item with similar goods, but more in number because the person exchanging requires such things, such as exchanging gold with gold, rice with rice, and so on. This kind of sale and purchase or exchange contains gharar (uncertainty), which is an injustice for both parties of the value of each item exchanged. For example, someone lends $100 \mathrm{~kg}$ of rice with more repayment requirements, for example $110 \mathrm{~kg}$ of rice of the same quality. ${ }^{18}$

In the modern context, riba nasî'ah is closely related to the practice of interest in money, especially interest that occurs in financial institutions. As the result of ijtima Ulama Indonesia on December 16th, 2003, that the practice of interest money in economic or financial transactions, whatever its form, whether it occurs in financial institutions (banks, insurance, etc.) or individuals between

${ }^{12}$ Muhammad Ali al-Shabuni, Rawa'I al-Bayan Tafsir Ayat al-Ahkam, (Beirut: Maktabah alGhazâlî, 2005), juz. 1, h. 383

${ }^{13}$ Adiwarnan A. Karim dan Oni Sahroni, Riba, Gharar dan kaidah-kaidah Ekonomi Syariah Analisis Fikih dan Ekonomi, (Jakarta: Rajawali Pers, 2015), h. 5-7; Muhammad Amin Suma, Tafsir Ayat Ekonomi, h. 170.

${ }^{14}$ Agus Rijal, Hutang Halal, Hutang Haram-Panduan Berhutang dan Sekelumit Permasalahan dalam Syariat Islam, (Jakarta: Kompas Gramedia, 2013), cet. ke-1, h.114

${ }^{15}$ Adiwarnan A. Karim dan Oni Sahroni, Riba, Gharar dan kaidah-kaidah Ekonomi Syariah Analisis Fikih dan Ekonomi, h. 28-31.

${ }^{16}$ Agus Rijal, Hutang Halal, Hutang Haram-Panduan Berhutang dan Sekelumit Permasalahan dalam Syariat Islam, h.114

${ }_{17}^{17}$ Muhammad Amin Suma, Tafsir Ayat Ekonomi, hlm. 170-171

${ }^{18}$ Definition in Al-Qur'an from Ministry of Religion translation. 
Jurnal Ekonomi dan Perbankan Syariah

Vol. 7. No.1, April 2019: 5-21, ISSN (cet): 2355-1755 | ISSN (online): 2579-

6437

19

humans is illegal because it fulfills usury criteria from the Prophet Muhammad PBUH. ${ }^{19}$

\section{Commodity of Usury Goods and Its Illat}

According to the hadith of Muslim history from 'Ubâdah bin Shâmit r.a. that the Prophet Muhammad PBUH said:

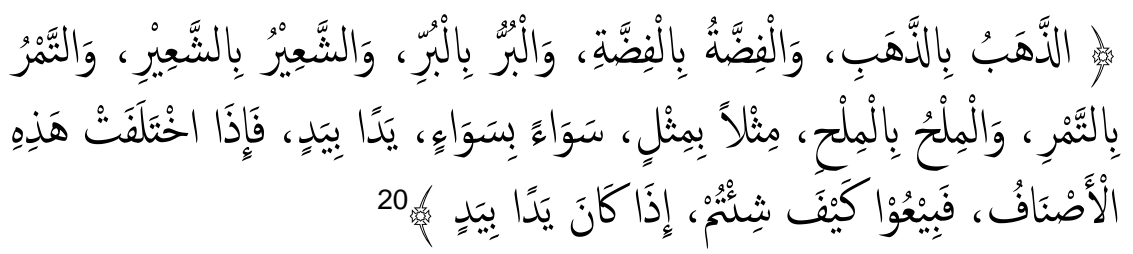

"Gold (paid) with gold, silver (paid) with silver, wheat (paid) with wheat, millet (paid) with millet, dates (paid) with dates, salt (paid) with salt, worth equal to the same value as the same type, cash (cash in place). If these types are different from each other, then sell as you wish (only) if cash" follows:

Based on the hadith above, the commodities of the usury goods are as

Table 1. The Commodities of The Usury Goods

\begin{tabular}{|c|c|}
\hline Type & Effective Reasons ('Illat) \\
\hline $\begin{array}{l}\text { 1. Gold } \\
\text { 2. Silver }\end{array}$ & Its capacity is the dominant currency \\
\hline $\begin{array}{l}\text { 3. Wheat } \\
\text { 4. Millet } \\
\text { 5. Dates } \\
\text { 6. Salt }\end{array}$ & The staple food is weighed or graded \\
\hline
\end{tabular}

The implication of the existence of 'illat in the six types of commodities of usury goods above is that anything that has similarity in terms of 'illat with the six types of commodities can also be categorized as usury goods, including paper currency which is used as a medium of exchange and capital investing,

\footnotetext{
${ }^{19}$ See more on Fatwa MUI No. 1 tahun 2004 tentang Bunga (Interest/Faedah).

${ }^{20} \mathrm{Al}-H a f i z h$ Abi al-Husain Muslim bin al-Hajjaj, Shahih Muslim, (Riyadh : Bayt al-Afkar alDauliyyah, 1998), Kitâb al-Musâqâh, Hadits No. 1587, h. 647
} 
10 | Asgaft Asy-syad Rasyid: Figh Solutions Againts Usury (Riba) Practices in Conventional Banking

where the exchange must meet the rules set in accordance with what is stated in the hadith of 'Ubâdah bin Shamit ra. above, i.e.. ${ }^{21}$

Table 2. The Exchange and The Rules

EXCHANGE

RULES

Two usury items that have the same The exchange must meet two

'illat and the same type conditions, namely: the same quantity, and cash.

For example, 10 grams of gold are exchanged for 10 grams of gold, paid in cash (not postponed or credit)

Two usury items that have similar 'illat but have different types
The exchange is not required in the same quantity but still has to be cash

For example, 10 grams of gold is exchanged for 1 million rupiah or silver in cash.
Two items that are either one or both are not usury items
The exchange is not required for the same quantity and does not have to be cash.

For example, 10 grams of gold or money exchanged with 1 quintal of rice / wheat, may be paid in cash or credit.
Two usury items that have a difference 'illat and its type
The exchange is not required for the same quantity and does not have to be cash.

For example, 1 house or car is exchanged for 10 motorbikes or money, may be paid in cash or credit.

21 Agus Rijal, Hutang Halal, Hutang Haram-Panduan Berhhutang dan Sekelumit Permasalahan dalam Syariat Islam, h.119-120 
Jurnal Ekonomi dan Perbankan Syariah

Vol. 7. No.1, April 2019: 5-21, ISSN (cet): 2355-1755 | ISSN (online): 25796437

\section{| 11}

\section{Usury versus Selling-Buying (Time Value of Money versus Economic Value Off time)}

Addition that occurs in usury transactions is a form of compensation for the value of time someone uses in borrowing money, in economic theory known as Time Value of Money. ${ }^{22}$ While the additions that exist in the selling-buying contract are obtained from the results of the endeavor (economically valuable business) which has underlaying contracts so that it is known as the Economic Value Off time.

So therefore, in selling-buying transactions the law of fiqh applies to buying and selling, such as the existence of objects of goods, prices of goods and so forth. ${ }^{23}$ Selling-buying is included in the business category, while usury is included in the social category. ${ }^{24}$

Although both transactions are oriented towards the existence of a profit, both of them have different laws. Profits from buying and selling are halal while the profits from usury are illegal. This happens because basically in character, in buying and selling there is a huge potential between profit and loss, all depends on the ability and expertise of the people who run it. Whereas in usury, in any context, whether the condition is profit or loss, it must always benefit the party who gives the loan.

From these two transactions it can be concluded that we are allowed to take advantage of transactions whose basis of contract is business (tijari). Whereas social contracts are unlawful to take advantage. If these two things can be done with istiqomah, then Allah will bestow blessings and sufficient sustenance. According to Al Quran Surat ath-Thalaq verse 2-3:

"And whoever fears Allah - He will make for him a way out. And will provide for him from where he does not expect. And whoever relies upon Allah - then He is sufficient for him. Indeed, Allah will accomplish His purpose. Allah has already set for everything a [decreed] extent."

\section{Usury in Conventional Banking}

Based on the understanding of the description of usury above, several conventional banking products and activities can be classified as classified as usury activities, namely:

\footnotetext{
${ }^{22}$ As was the practice in the age of Jahiliyah which is known as Riba Nasî'ah and practices on interest money on conventional banks.

${ }^{23}$ See more on Fatwa DSN-MUI no. 04, 110 dan 111.

${ }^{24}$ Usury appears in the debt contract (al-qardh).
} 
12 | Asgaft Asy-syad Rasyid: Fiqh Solutions Againts Usury (Riba) Practices in Conventional Banking

Table 3. Usury in Conventional Banking: Product and Activity

\begin{tabular}{ll}
\hline Name of Product or Activity & \multicolumn{1}{c}{ Remarks on Riba (Usury)* } \\
$\begin{array}{l}\text { Deposits from customers } \\
\text { (Demand Deposits, Savings, } \\
\text { Other Deposits) }\end{array}$ & $\begin{array}{l}\text { The bank provides interest payments } \\
\text { on each customer deposit product. } \\
\text { This is classified as the practice of } \\
\text { riba fadhl. }\end{array}$ \\
\hline Credit / loan (debts) & $\begin{array}{l}\text { The bank takes interest (additional) as } \\
\text { an advantage on each loan given to } \\
\text { customers. This is classified as the } \\
\text { practice of riba nasiah. }\end{array}$ \\
\hline The bank takes interest (additional) as \\
an advantage on each loan given to \\
customers. This is classified as the \\
practice of riba nasiah.
\end{tabular}

* Agreed and become a requirement in the contract document between the bank and the customer

From this classification, it can be seen that not all conventional bank products can be classified as usury practices, but only on products based on debt and credit contracts. Whereas in products that have no elements of debt or credit in them, then this is still in the khilafiyah realm. Such as the use of ATMs, SDB (save deposit box), traffic payment services (electricity, credit, taxes, shopping etc.) and so forth.

Thus, we can conclude that the interest of money that occurs in conventional banking is the practice of usury, because it is in accordance with the definition of usury itself. However, not all conventional bank products are automatically classified as usury practices ${ }^{25}$, so that the opinions of Islamic scholars about the illegitimate practice of interest in banking must still be a concern and reference for every Muslim. ${ }^{26}$

\footnotetext{
${ }^{25}$ Only products that use the Qardh contract (accounts payable) with interest (additional) as profit

${ }^{26}$ The Fatwa of Majelis Ulama Indonesia prohibits the practice of interest in financial institutions, such as banks, insurance, capital markets, finance companies, cooperatives and so on.
} 
Jurnal Ekonomi dan Perbankan Syariah

Vol. 7. No.1, April 2019: 5-21, ISSN (cet): 2355-1755 | ISSN (online): 2579-

6437

| 13

\section{METHODOLOGY}

In this paper, the author uses the descriptive method, and analyzes fiqh muamalah reviews and the practice provisions in the MUI DSN fatwa. According to Nawawi, descriptive and analytical methods are intended to provide data that researchers set about humans, circumstances, or variations in other symptoms. In addition, the author also made observations to analyze the practices of conventional banks and Islamic banks which were later published on the comparison and differences of these practices. ${ }^{27}$

Data processing in this paper is to weigh, filter, organize and classify some literature. So in the context with the title above, for data that is documentary or library research, the author uses qualitative data analysis, namely data that cannot be measured or assessed directly by numbers. ${ }^{28}$

\section{DISCUSSION}

\section{ISLAMIC BANKS: EFFORTS TO AVOID USURY IN CONVENTIONAL BANKING}

\section{Definition of Islamic Banking}

Islamic banks are financial intermediaries that function as intermediaries that bring together people who raise funds (parties with excess funds) in the form of deposits and redistribute the funds to other people who need them based on sharia principles. Islamic banks are financial intermediaries that function as intermediaries that bring together people who have excess funds in the form of deposits and redistribute funds to other people who need them based on sharia principles.

The sharia principle in question is an agreement based on Islamic law between the bank and the customer for depositing funds, financing business activities or other activities. In the context of Islamic banking in Indonesia, this sharia rule must refer to the fatwa issued by the Majelis Ulama Indonesia, in this case the National Sharia Council (Dewan Syariah Nasional). ${ }^{29}$

\section{Are Islamic Banks the Same as Conventional Banks?}

It is not entirely wrong when someone states that the Islamic bank is the same as a conventional bank. But what needs to be questioned is how are they similar? Yogyakarta.

${ }^{27}$ Nawawi, H. Hadari. 1983. Metode Penelitian Deskriptif. Gajah Mada University Press.

${ }^{28}$ Amirin, M. Tatang, (2000). Menyusun Rencana Penelitian, Edisi 1, Cetakan Keempat, Penerbit Raja Grafindo Persada, Jakarta.

${ }^{29}$ Undang-Undang Perbankan Syariah No. 21 tahun 2008 pasal 2 

Banking

In his book The Role of Values and Morals (in Islamic economics) Yusuf Qaradhawi states that in Islamic economic concepts, religious values and morals cannot be separated from economic behavior. When an economic act is not in accordance with religious values and morals, it is a mistake. ${ }^{30}$ Dalam praktek perbankan, segala sesuatu yang haram menurut agama Islam yang terdapat di dalam praktek Bank Konvensional tidak boleh terjadi di dalam Bank Syariah. In banking practice, everything that is illegitimate according to the Islamic religion contained in conventional Bank practices may not occur within a Sharia Bank.

What needs to be stressed here is that both are financial institutions that have the function of funding (collecting funds from the public) and landing (channeling funds to the public). But in practice it is certainly much different, because Islamic banks only carry out matters justified by the Islamic sharia, and to obtain benefits - both in terms of funding, landing and Islamic banking services - using business contracts. So that in practice, Islamic Banking cannot use the qardh contract (accounts payable) as the basis for business transactions that are carried out. ${ }^{31}$ As practiced by conventional banks that make debt accounts (credit) the main foundation of the business they run.

\section{The Differences in Conventional Bank Credit \& Financing (Tamwil) of Islamic Banks}

In muamalah study there are rules of fiqh "Everything is legal except if there is a proposition that shows its prohibition". This is in line with the opinion of Sayyid Qutb in his book Tafsir fi Zhilal al-Qur'an, that in carrying out Islamic economic practices it does not necessarily eliminate all concepts contained in conventional banking. But it is enough to leave things that are prohibited. So that in practice banking in accordance with Islamic sharia must leave everything that is forbidden contained in conventional banking. Among them are the practice of maysir (gambling and speculation), gharar (obscurity), usury and other elements that contain injustice or injustice. What then is banking practice like this is known as "Islamic Bank".

In muamalah study there are rules of fiqh "Everything is legal except if there is a proposition that shows its prohibition". This is in line with the opinion of Sayyid Qutb in his book Tafsir fi Zhilal al-Qur'an, that in carrying out Islamic economic practices it does not necessarily eliminate all concepts contained in conventional banking. But it is enough to leave things that are prohibited. So that in practice banking in accordance with Islamic sharia must leave everything that is forbidden contained in conventional banking. Among them are the practice of maysir (gambling / speculation / gambling), gharar (obscurity), usury and other elements that contain injustice or injustice. What then is banking practice like this is known as "Islamic bank".

\footnotetext{
${ }^{30}$ See more on: Yusuf Qaradhawi, Peran Nilai dan Moral Dalam Perekonomian Islam, (Jakarta; Robbani Perss, 2004), h. 3-6

${ }^{31}$ Transaksi bisnis (tijari) yang digunakan oleh Bank Syariah tidak boleh menggunakan akad utang piutang (qardh). Karena adanya tambahan/keuntungan dalam akad utang piutang tergolong sebagai riba.
} 
Jurnal Ekonomi dan Perbankan Syariah

Vol. 7. No.1, April 2019: 5-21, ISSN (cet): 2355-1755 | ISSN (online): 25796437

15

Credit contracts run at conventional banks do not have underlying contracts, namely banks do not require loan money given to customers only to be used on certain matters, meaning that the use of money is handed over to customers, want to be used for financing halal or non-halal. Conventional banks will usually only ensure that there is collateral (collateral) that is owned by the customer to guarantee the amount of debt obtained. So that in this practice the transaction that occurs is money meets money with an agreed addition (interest). The concept of such a credit agreement does not occur in Islamic banking. Islamic banking uses the concept of financing (tamwîl). In addition to the use of funds given to customers, they must not conflict with sharia principles, the use of these funds must also have clear underlaying. Used to buy something, for business capital, for rental activities or services and so forth.

So that in practice all business activities of Islamic banks, be it fund raising, financing business activities, providing services and other activities must have a clear underlying purpose so that it must use contracts in accordance with sharia principles.

The contracts adopted by Islamic banking in Indonesia are as follows: ${ }^{32}$

1. Murabahah, the principle of buying and selling goods and assets by gaining profits;

2. Mudharabah, giving business capital based on the principle of profit sharing;

3. Musharakah, business capital participation based on the principle of profit sharing;

4. Ijarah, financing of capital goods based on the principle of pure rent without choice;

5. Ijarah Muntahiyah bi at-Tamlik, cooperation with the principle of leasing and with the transfer of ownership options at the end, either with grants or selling-buying;

6. Musyarakah Mutanaqishah, cooperation in capital participation in the framework of ownership of an asset with the gradual transfer of ownership to one of the parties to $100 \%$;

7. Hawalah, Kafalah, Wakalah, provision of services with the concept of representation, guarantee and transfer of debt;

8. Rahn, the concept of pawn to get a loan;

9. Qardh, the concept of lending without any additional benefits or interest, etc. Especially in the qardh contract, Islamic banking only uses it for social activities (not profit oriented). Such as financing to internal employees, corporate social responsibility (CSR) activities and so on, without any benefits taken by the bank.

${ }^{32}$ Buku Himpunan Fatwa Keuangan Syariah, Dewan Syariah Nasional - Majelis Ulama Indonesia. 
16 | Asgaft Asy-syad Rasyid: Fiqh Solutions Againts Usury (Riba) Practices in Conventional Banking

In addition, differences also occur in the process when fines occur, customers have problems until the execution of the guarantee. ${ }^{33}$

Regarding supervision, to safeguard and ensure that Islamic banking runs on its corridors, in accordance with sharia principles, then in addition to being supervised by OJK (Otoritas Jasa Keuangan) as financial services authority and BI (Bank Indonesia). Islamic banks are also supervised by DSN-MUI (Dewan Syariah Nasional- Majelis Ulama Indonesia) related to the application of sharia principles in each of its activities. Of course, this adds to the sense of comfort and calm for Muslims in carrying out economic activities in Islamic banking, which is guaranteed.

The following are examples of products found in Islamic banking which are compiled based on fiqh studies and regulations that apply in Indonesia:

Table 4. Product and Activity of Islamic Banking and Its Benefits

\begin{tabular}{|c|c|c|c|}
\hline No & $\begin{array}{l}\text { Product } \\
\text { and } \\
\text { Activity }\end{array}$ & Contract & Benefits \\
\hline \multicolumn{4}{|c|}{ Financing } \\
\hline \multirow[b]{2}{*}{1} & \multirow[b]{2}{*}{$\begin{array}{l}\text { Demand } \\
\text { Deposit }\end{array}$} & Mudharabah & $\begin{array}{l}\text { Profit sharing is expressed in the } \\
\text { form of a profit-sharing ratio agreed } \\
\text { between the bank and the customer. }\end{array}$ \\
\hline & & Wadi'ah & $\begin{array}{l}\text { There is no reward, except in the } \\
\text { form of voluntary gifts from the bank } \\
\text { ('athaya). }\end{array}$ \\
\hline \multirow{2}{*}{2} & \multirow{2}{*}{ Saving } & Mudharabah & $\begin{array}{l}\text { Profit sharing is expressed in the } \\
\text { form of profit-sharing ratio agreed } \\
\text { between the bank and the customer. }\end{array}$ \\
\hline & & Wadi'ah & $\begin{array}{l}\text { There is no compensation required, } \\
\text { except in the form of voluntary } \\
\text { giving from the bank ('athaya). }\end{array}$ \\
\hline 3 & Deposit & Mudharabah & $\begin{array}{l}\text { - Capital must be expressed in } \\
\text { cash rather than receivables. } \\
\text { - Distribution of profits is stated in } \\
\text { the form of profit-sharing ratio } \\
\text { agreed between the bank and the } \\
\text { customer. }\end{array}$ \\
\hline \multicolumn{4}{|c|}{ Financing } \\
\hline
\end{tabular}

${ }^{33}$ Selengkapnya pada Fatwa DSN-MUI tentang Ta'zir dan Ta'widh 
Jurnal Ekonomi dan Perbankan Syariah

Vol. 7. No.1, April 2019: 5-21, ISSN (cet): 2355-1755 | ISSN (online): 2579-

6437

| 17

\begin{tabular}{|c|c|c|c|}
\hline \multirow{3}{*}{1} & \multirow{3}{*}{$\begin{array}{l}\text { Purchase of } \\
\text { assets (land, } \\
\text { buildings, } \\
\text { vehicles, } \\
\text { etc.) }\end{array}$} & Murabahah & $\begin{array}{l}\text { Margin (Difference between the cost } \\
\text { of goods and the selling price of an } \\
\text { asset). }\end{array}$ \\
\hline & & $\begin{array}{l}\text { Musyarakah } \\
\text { Mutanaqishah } \\
(M M Q)\end{array}$ & $\begin{array}{l}\text { Profit sharing ratio and ujrah (fee) of } \\
\text { assets leased. }\end{array}$ \\
\hline & & $\begin{array}{l}\text { Ijarah } \\
\text { Muntahiyah } \\
\text { Bittamlik } \\
\text { (IMBT) \& } \\
\text { Ijarah } \\
\text { Maushufah fi } \\
\text { Dzimmah } \\
\text { (IMFZ) }\end{array}$ & $\begin{array}{l}\text { - Ujrah (fee) of assets leased with } \\
\text { an option to transfer ownership at } \\
\text { the end of the lease period } \\
\text { (IMBT). } \\
\text { - Indent assets (IMFZ). }\end{array}$ \\
\hline \multirow{3}{*}{2} & \multirow{3}{*}{$\begin{array}{l}\text { Working } \\
\text { capital }\end{array}$} & Musyarakah & $\begin{array}{l}\text { Profit sharing is expressed in the } \\
\text { form of profit-sharing ratio agreed } \\
\text { between the bank and the customer. }\end{array}$ \\
\hline & & Mudharabah & $\begin{array}{l}\text { Profit sharing is expressed in the } \\
\text { form of profit-sharing ratio agreed } \\
\text { between the bank and the customer. }\end{array}$ \\
\hline & & $\begin{array}{l}\text { Musyarakah } \\
\text { Mutanaqishah } \\
\text { (MMQ) }\end{array}$ & $\begin{array}{l}\text { Profit sharing ratio and fee (fee) of } \\
\text { assets leased. }\end{array}$ \\
\hline \multirow{3}{*}{3} & \multirow{3}{*}{ Investing } & Murobahah & $\begin{array}{l}\text { Margin (Difference between the cost } \\
\text { of goods and the selling price of an } \\
\text { asset). }\end{array}$ \\
\hline & & $\begin{array}{l}\text { Musyarakah } \\
\text { Mutanaqishah }\end{array}$ & $\begin{array}{l}\text { Profit sharing ratio and ujroh (fee) of } \\
\text { assets leased. }\end{array}$ \\
\hline & & $\begin{array}{l}\text { Ijarah } \\
\text { Muntahiyah } \\
\text { Bittamlik } \\
\text { (IMBT) \& } \\
\text { Ijarah } \\
\text { Maushufah fi }\end{array}$ & $\begin{array}{l}\text { - Ujrah (fee) of assets leased with } \\
\text { an option to transfer ownership at } \\
\text { the end of the lease period } \\
\text { (IMBT). } \\
\text { - Indent assets (IMFZ). }\end{array}$ \\
\hline
\end{tabular}


18 | Asgaft Asy-syad Rasyid: Fiqh Solutions Againts Usury (Riba) Practices in Conventional Banking

\begin{tabular}{|c|c|c|c|}
\hline & & $\begin{array}{l}\text { Dzimmah } \\
\text { (IMFZ) }\end{array}$ & \\
\hline \multirow[t]{3}{*}{4} & \multirow{3}{*}{$\begin{array}{l}\text { Take over } \\
\text { from fellow } \\
\text { Islamic } \\
\text { banks }\end{array}$} & $\begin{array}{l}\text { Musyarakah } \\
\text { Mutanaqishah } \\
\text { (MMQ) }\end{array}$ & $\begin{array}{l}\text { Profit sharing ratio and ujrah (fee) of } \\
\text { assets leased. }\end{array}$ \\
\hline & & $\begin{array}{l}\text { Ijarah } \\
\text { Muntahiyah } \\
\text { Bittamlik } \\
\text { (IMBT) }\end{array}$ & $\begin{array}{l}\text { Ujrah (fee) of assets leased with an } \\
\text { option to transfer ownership at the } \\
\text { end of the lease period. }\end{array}$ \\
\hline & & $\begin{array}{l}\text { Hawalah Bil } \\
\text { Ujroh }\end{array}$ & $\begin{array}{l}\text { Ujrah (fee) for debt payment } \\
\text { services. }\end{array}$ \\
\hline \multirow[t]{4}{*}{5} & \multirow{4}{*}{$\begin{array}{l}\text { Take over } \\
\text { from a } \\
\text { conventional } \\
\text { bank }\end{array}$} & $\begin{array}{l}\text { - Qardh } \\
\text { - Murabahah }\end{array}$ & $\begin{array}{l}\text { Margin (The difference between the } \\
\text { cost of goods and the selling price of } \\
\text { an asset). }\end{array}$ \\
\hline & & $\begin{array}{l}\text { - Musyarakah } \\
\text { (Syirkatul } \\
\text { Milk) } \\
\text { - Murabahah } \\
\text { Atau MMQ }\end{array}$ & $\begin{array}{l}\text { Margin (The difference between the } \\
\text { cost of goods and the selling price of } \\
\text { an asset). }\end{array}$ \\
\hline & & - $\quad$ Ijarah & Ujroh (fee) for bank services. \\
\hline & & $\begin{array}{l}\text { - } \quad \text { Qardh } \\
\text { - } \quad I M B T\end{array}$ & $\begin{array}{l}\text { Ujroh (fee) of assets leased with an } \\
\text { option to transfer ownership at the } \\
\text { end of the lease period. }\end{array}$ \\
\hline 6 & $\begin{array}{l}\text { Sharia } \\
\text { Refinancing }\end{array}$ & $\begin{array}{l}\text { Musyarakah } \\
\text { Mutanaqishah } \\
\text { (MMQ) }\end{array}$ & $\begin{array}{l}\text { Profit sharing ratio and } u j r o h \text { (fee) of } \\
\text { assets leased }\end{array}$ \\
\hline
\end{tabular}


Jurnal Ekonomi dan Perbankan Syariah

Vol. 7. No.l, April 2019: 5-21, ISSN (cet): 2355-1755 | ISSN (online): 2579-

6437

19

\section{CONCLUSION}

Yusuf Qaradhawi stated that in Islamic economic concepts, religious values and morals cannot be separated from economic behavior. When an economic act is not in accordance with religious values and morals, it is a mistake.

Islamic banks only carry out matters justified by the Islamic Shari'a, and to obtain benefits - both in terms of funding, landing and services - Islamic banks use tijârî (business) contracts as a basis for business transactions that are carried out.

Selling-buying is part of the business category (tijârî), while usury is included in the social domain (tabarru). Although both transactions are both profit-oriented, they both have different laws. The advantages of selling-buying are halal while the benefits of usury are illegal. This happens because basically, in buying and selling, there is a huge potential between profit and loss, while in usury, in any context, whether profit or loss, it must always benefit the party giving the loan. 
20 | Asgaft Asy-syad Rasyid: Figh Solutions Againts Usury (Riba) Practices in Conventional Banking

\section{BIBLIOGRAPHY}

Al-'Arabiyah, Majma’ al-Lughah .(2004). Al-Mu'jam al-Wasîth, Cairo: Maktabah asy-Syurûq ad-Dawliyah.

Amirin, M. Tatang. (2000). Menyusun Rencana Penelitian, Edisi 1, Cetakan Keempat, Penerbit Raja Grafindo Persada, Jakarta.

Ayyub, Hasan. (2004) Fiqh al-Mu 'âmalât al-Mâliyah fî al-Islâm, Cairo: Dâr asSalâm.

Buku Himpunan Fatwa Keuangan Syariah, Dewan Syariah Nasional - Majelis Ulama Indonesia.

Fatwa DSN-MUI tentang Ta'zir dan Ta'widh.

Fatwa MUI No. 1 tahun 2004 tentang Bunga (Interest/Faedah).

Ifham, Ahmad. (2015). Ini Lho Bank Syariah (Memahami Bank Syariah dengan Mudah). Jakarta: Gagas Media, 2015;

Imani, Allamah Kamal Faqih. (2003). Tafsir Nurul Qur'an. Jakarta: Al-Huda, 2003;

Jalaluddin Al-Mahalli \& As-Suyuti. (2018). Terjemahan Tafsir Jalalain, Bandung: Sinar Baru Algresindo, 2018;

Karim, Adiwarnan A. dan Oni Sahroni. (2018). Riba, Gharar dan kaidah-kaidah Ekonomi Syariah Analisis Fikih dan Ekonomi. Jakarta: Rajawali Pers, 2015;

Kasmir, (2005) Bank dan Lembaga Keuangan Lainnya. Jakarta: PT. RajaGrafindo.

Muslim, Al-Hafizh Abi al-Husain. (1998). Shahih Muslim. Riyadh: Bayt alAfkar al-Dauliyyah, 1998;

Nawawi, H. Hadari. (1983). Metode Penelitian Deskriptif. Yogyakarta: Gajah Mada University Press.

Peraturan Bank Indonesia No. 11/33 tahun 2009 tentang GCG bagi BUS \& UUS

Qaradhawi, Yusuf. (2004). Peran Nilai dan Moral Dalam Perekonomian Islam. Jakarta; Robbani Perss.

Quthb, Sayyid. (2018). Tafsir Ayat-Ayat Riba (Mengupas Persoalan Riba Sampai ke Akar-akarnya). Jakarta: Wali Pustaka, cet. ke-1, 2018;

Rijal, Agus. (2013). Hutang Halal, Hutang Haram-Panduan Berhhutang dan Sekelumit Permasalahan dalam Syariat Islam. Jakarta: Kompas Gramedia.

ash-Shâbûnî, Muhammad Ali. (2005). Rawâ'i 'al-Bayan fî Tafsîr Âyât al-Ahkâm. Beirut: Maktabah al-Ghazali. 
Jurnal Ekonomi dan Perbankan Syariah

Vol. 7. No.1, April 2019: 5-21, ISSN (cet): 2355-1755 | ISSN (online): 2579-

6437

| 21

ash-Shâbûnî, Muhammad Ali. (2018). Ringkasan Tafsir Ibnu Katsir cet. ke-4. Bandung: Jabal

Shihab, M. Quraish. (2011). Tafsir Al Misbah, Jakarta: Lentra Hati.

Suma, Muhammad Amin. (2018). Tafsir Ayat Ekonomi cet. Ke-3. Jakarta: Amzah.

Suratmaputra, A. Munif. (2016). Hukum Islam Problematika dan Solusinya. Jakarta: Pustaka Firdaus

Undang-Undang Perbankan Syariah No. 21 tahun 2008 pasal 2 